\title{
Preliminary Starch Grain Evidence of Ancient Stone Tool Use at the Early Archaic ( 9,000 B.P.) Site of Sandy Hill, Mashantucket, Connecticut
}

\author{
Thomas C. Hart ${ }^{1^{*}}$ and Timothy H. Ives ${ }^{2}$ \\ Author address: ${ }^{1}$ Department of Anthropology, University of Connecticut, Beach Hall U-1176, 354 Mansfield Road, Storrs, \\ Connecticut 06269 USA. ${ }^{2}$ Rhode Island Historical Preservation \& Heritage Commission, The Old State House, 150 Benefit \\ Street, Providence, Rhode Island 02903, USA. \\ *Corresponding author: thomas.hart@uconn.edu
}

Received: May 16, 2013

Published: September 2, 1013

Volume: 4:87-95

(C) 2013 Society of Ethnobiology

\begin{abstract}
Early Archaic subsistence strategies of New England remain poorly understood despite their importance in helping researchers understand how people adapt to changing landscapes following the end of the last glacial maximum $(21,000-$ 14,000 B.P.). Excavations at the Mashantucket Pequot Reservation in Mashantucket, Connecticut during the 1990s revealed a large, semi-sedentary village nestled alongside a complex wetland ecosystem. In this paper, we present preliminary starch grain analysis of several stone tools recovered and curated from these excavations. The results of this study indicate that both transitory and reserve starch grains are preserved on these artifacts and that at least one of the artifacts may have been used for leaf or stem processing. The results of this study also demonstrate the potential for future research in which paired macrobotanical and residue analysis will allow for a better understanding of subsistence practices at the site and during the early Archaic in general.
\end{abstract}

Key Words: paleoethnobotany, starch grains, New England, Early Archaic, lithics

\section{Introduction}

Starch grain analysis is fast becoming a mainstay of archaeological and palaeoethnobotanical research and is useful for understanding ancient plant use practices and reconstructing paleoenvironments where the preservation of other types of remains such as charred seeds and wood, phytoliths, and pollen is poor (Torrence and Barton 2006). The early Archaic (9000 -7000 B.P.) of southern New England remains an enigma in terms of subsistence practices despite its importance in helping researchers understand how people adapt to changing landscapes following the last glacial maximum (21 - 14 kya B.P) (McWeeney 1999). The extensive stone tool assemblage recovered from the early Archaic site of Sandy Hill at the Mashantucket Pequot Reservation in Mashantucket, Connecticut presents a unique opportunity to explore how the inhabitants of this semi-sedentary village adapted to changing environmental conditions. This study highlights the potential use of starch grains found on museum curated stone tools for reconstructing plant use practices at this site.

Starch grains are microscopic semi-crystalline structures typically produced in the amyloplasts and chloroplasts of plant cells and are composed of alternating layers of amylose and amylopectin carbohydrate molecules (Torrence and Barton 2006). Storage starch grains, also known as "reserve" starch grains, are produced in the amyloplasts of corms, rhizomes, roots, tubers, seeds and fruits, and serve as a source of energy for plants during periods of germination, hibernation, and/ or dormancy (Perry 2011; Piperno 2006; Torrence and Barton 2006). Because features of a starch grain such as the shape, size, hilum, extinction cross, cracks or fissures, lamellae, and surface texture are under strong genetic control, variations in these features are used to identify storage starch grains to a genus, species, or sometimes even variety level (Reichert 1913). "Transitory" starches, also known as "leaf" or "assimilation" starch grains, are smaller (typically less than five $\mu \mathrm{m}$ ), and produced in the chloroplasts of leaves and other green tissues, and serve as temporary forms of energy storage that are utilized by plants immediately following the completion of their photoperiod (Haslam 2004).

Southeastern Connecticut's Sandy Hill site (also known as CT Site 72-97) (Figure 1) is located on the Mashantucket Pequot Reservation and has been 


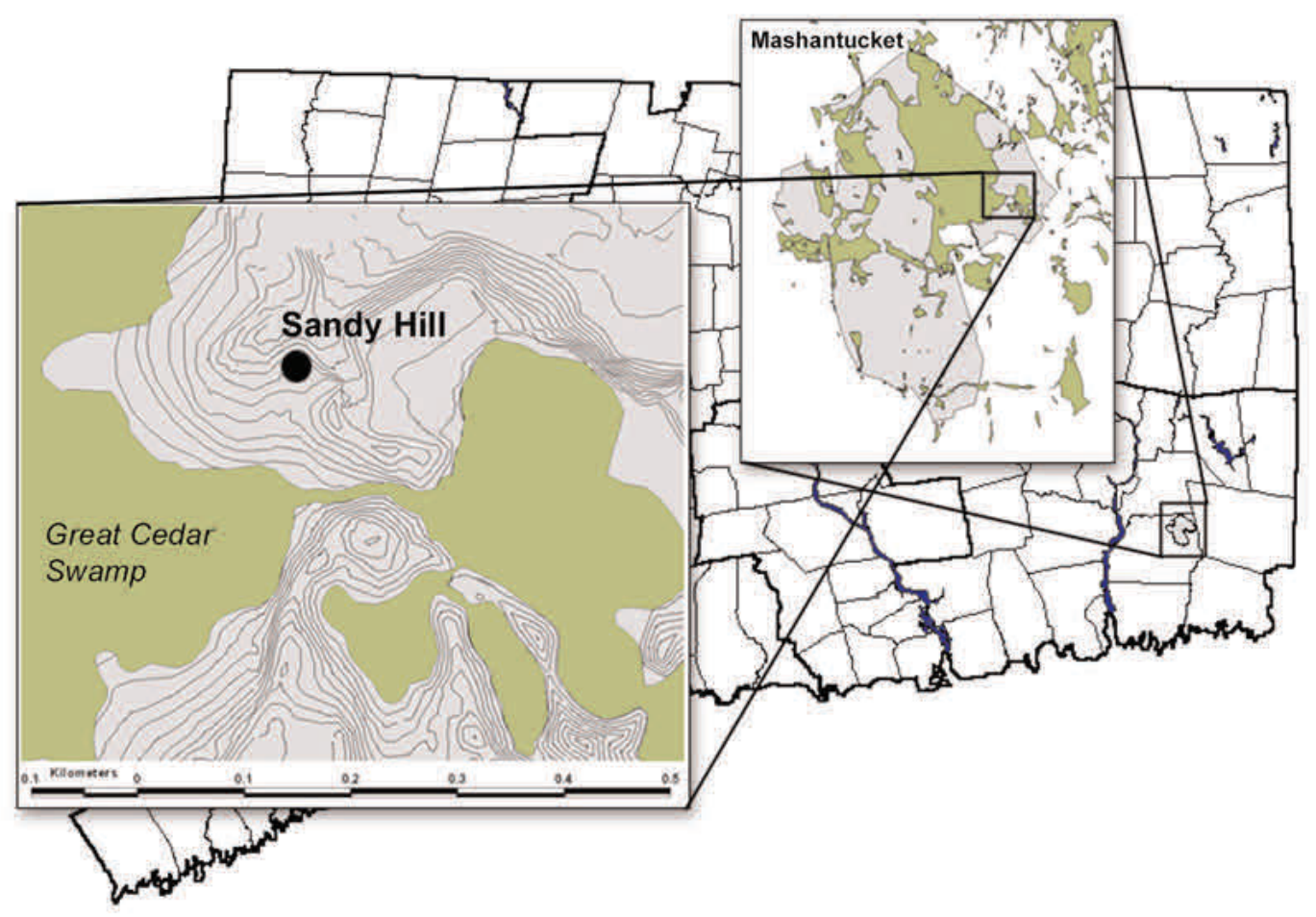

Figure 1. Location of Sandy Hill at the Mashantucket Pequot Reservation, Ledyard, Connecticut (adapted from Jones and Forrest 2003: 75).

repeatedly excavated by the Mashantucket Pequot Museum and Research Center (hereafter MPMRC) in collaboration with the University of Connecticut's Department of Anthropology. The most productive was a large-scale excavation $\left(5,358 \mathrm{~m}^{2}\right)$ from 1996 to 1997 that mitigated portions of the Sandy Hill site prior to development impacts associated with the expanding Foxwoods Casino complex. These efforts revealed a large multicomponent site dating back to the Terminal Pleistocene (Forrest 1999) that contained over 300,000 artifacts. The site's most archaeologically robust component spans the 9th millennium B.P. and manifests the Gulf of Maine Archaic tradition (hereafter GMAT); an Early-to-Middle Holocene archaeological complex (14,000 - 5000 B.P.) endemic to New England distinguished by enigmatic stone tool technologies and a notably ancient adaptation to wetland environments (McWeeney 1999; Robinson and Peterson 1993).

Sandy Hill lies near the rim of the Great Cedar Swamp basin, a large area that harbored a complex wetland system during the Early Holocene featuring wooded, swamp, marsh, and open-water habitats (Jones and Forrest 2003; McWeeney 1994; Thorson and Webb 1991). The site's ${ }^{14} \mathrm{C}$ date series $(9340 \pm 60$ B.P. $-1010 \pm 40$ B.P.) (Table 1) indicates multiple occupations with the earliest occupation coinciding with the existence of this wetland system and ends with the advance of the Hypsithermal drying trend that turned the basin floor into a brushy field (Forrest 1999). Carbon-rich "black sand" layers at stratified GMAT sites suggest intensive occupations (Robinson and Peterson 1993), an interpretation that is wellsupported at Sandy Hill where such layers constitute the remnants of pit-house floors (Forrest 1999). These floors contained abundant macrobotanical remains including carbonized fuelwood, hazelnut shells, and parenchymous tissues. Analysis of parenchymous tissues revealed the utilization of species associated with disturbed wetland and field environments such as Cattails (Typha sp. Linnaeus Poales: Typhaceae) and Yellow nutsedge (Cyperus esculentus Linnaeus Poales: 
Table 1. Carbon ${ }^{14}$ dates of early Archaic occupation from Sandy Hill (adapted from Jones and Forrest 2003: 85).

\begin{tabular}{lllll}
\hline Lab Number & Measured ${ }^{13} \mathrm{C}$ Age & ${ }^{13} \mathrm{C} /{ }^{12} \mathrm{C}$ Ratio & ${ }^{13} \mathrm{C}$ Adjusted Age & Dated Carbonized Material \\
\hline Beta-113499 & $8490 \pm 60$ & -24.1 & $8510 \pm 60$ & Typha sp. \\
Beta-162837 & $8570 \pm 60$ & -25.1 & $8570 \pm 60$ & Corylus sp. \\
Beta-162872 & $8630 \pm 50$ & -23.4 & $8660 \pm 50$ & Corylus sp. \\
Beta-126812 & $8660 \pm 60$ & -26.6 & $8640 \pm 60$ & Unid. plant tissue \\
Beta-126816 & $8680 \pm 60$ & -26.1 & $8660 \pm 60$ & Unid. plant tissue \\
Beta-113498 & $8710 \pm 60$ & -27.7 & $8670 \pm 60$ & Typha sp. \\
Beta-102564 & $8920 \pm 100$ & Est. -25.00 & $8920 \pm 100$ & Corylus sp. \\
Beta-162920 & $8960 \pm 40$ & -24.7 & $8960 \pm 40$ & Unid. plant tissue \\
Beta-122014 & $9020 \pm 60$ & -25.8 & $9000 \pm 60$ & Corylus sp. \\
Beta-122013 & $9340 \pm 60$ & -25.2 & $9340 \pm 60$ & Unid. wood \\
\hline
\end{tabular}

Cyperaceae) (D. Perry 1998, 1999, 2000). These findings are consistent with Early Holocene environmental reconstructions that place Sandy Hill in a complex wetland ecosystem (McWeeney 1994; Thorson and Webb 1991).

While the macrobotanical record allows us to reasonably infer that the foragers at Sandy Hill followed the GMAT tradition of exploiting wetland plant resources, the relationship between their stone tool technologies and mode of food production remains unknown. Stone tool assemblages curated in museums, such as those housed at the MPMRC, offer the opportunity to articulate technology with subsistence practice by analyzing ancient starch grains embedded in the stone tools. This pilot project reports on the starch grains embedded in several stone tools recovered from this site.

\section{Materials and Methods}

Recent advances in artifact residue analysis (Barton 2007; Hart 2011) have made it possible to analyze museum artifacts that were recovered before modern protocol were established to prevent contamination. It is important to be able to reconstruct handling events from the time an artifact was first discovered in the field until the time it was sampled for residue analysis.
Understanding these events and their sequence helps researchers to determine the level of post-depositional contamination associated with the artifact. It is assumed that the deeper the residues are found on an artifact's surface, the more likely they are to be associated with its original use. While archaeological residues may be directly sampled from the surface of an uncontaminated artifact (Barton 2007; Piperno et al. 2004), if an artifact is contaminated with younger residues, it is necessary to systematically strip them away to isolate, collect, and identify older residues associated with the artifact's original use. This study combines the utilization of museum artifacts as proposed by Barton (2007) with efforts to mitigate contamination as proposed by Hart (2011).

Various techniques for sampling artifacts for starch grain analysis exist (Pearsall 2000; Piperno 2006; Torrence and Barton 2006). The stone tools from Sandy Hill were systematically sampled using protocol established by Chandler-Ezell and Pearsall (2003) and Hart (2011) whereby three samples designated as sediments 1,2 , and 3 were taken from each artifact. This approach assumes that different proportions, abundances, and varieties of starch grains present in each sediment (or layer) reflect differing degrees of post-depositional contamination. The 
outermost sediment 1 samples are most likely to contain abundant materials from surrounding (loosely adhering) soil matrix. Sediment 2 samples are likely contaminated, but may contain some primary (userelated) residue freed from the artifact surface. The innermost sediment 3 samples should be free of contamination. See Hart (2011) for an illustration of this assumption and how the sediment samples are removed.

Three stone tools (one large laminar debris specimen, one small laminar debris specimen, and one large quartzite "hoe") were chosen for analysis from the museum collections at MPMRC. The large laminar debris and the small laminar debris were chosen because they had visible dirt adhering to their surfaces and came from occupational strata within a pit house feature. Though not directly dated, these strata are presumed to be $9^{\text {th }}$ millennium B.P. depositions according to the radiocarbon date series collected from the site's greater pit-house complex (Forrest 1999). The quartzite hoe was chosen because it was unwashed after being recovered in the field and was one of the two major classes of stone artifacts recovered from the site (the other being small microliths like the small and large laminar debris). The quartzite hoe is made of locally available quartzite and was one of five hoe-like forms cached in a pit-house floor stratum. A charred wood sample from this stratum yielded an uncalibrated AMS date of $8610 \pm$ 60 B.P. (Beta-226145).

The three stage removal process described above was deemed necessary to systematically recover starch grains associated with primary deposition and remove potential contamination from the outer surfaces of each artifact. The laminar debris specimens were sampled in their entirety because they were small and contained trace amounts of sediments, while only the front edge of the quartzite hoe was sampled because it contained visible sediments. The artifacts were removed from storage using sterile, powder-free nitrile gloves and were initially photographed to document potential areas of residue deposition. Once photographed, the laminar debris specimens were placed into individual sterile ziplock bags where their residues were removed systematically. The quartzite hoe was set aside and covered with sterile paper towels until its residues were removed. All residues were processed at the Paleoethnobotany Laboratory at the University of Missouri, Columbia, via the standard MU "piggyback" method designed to simultaneously extract phytoliths and starch grains from artifact

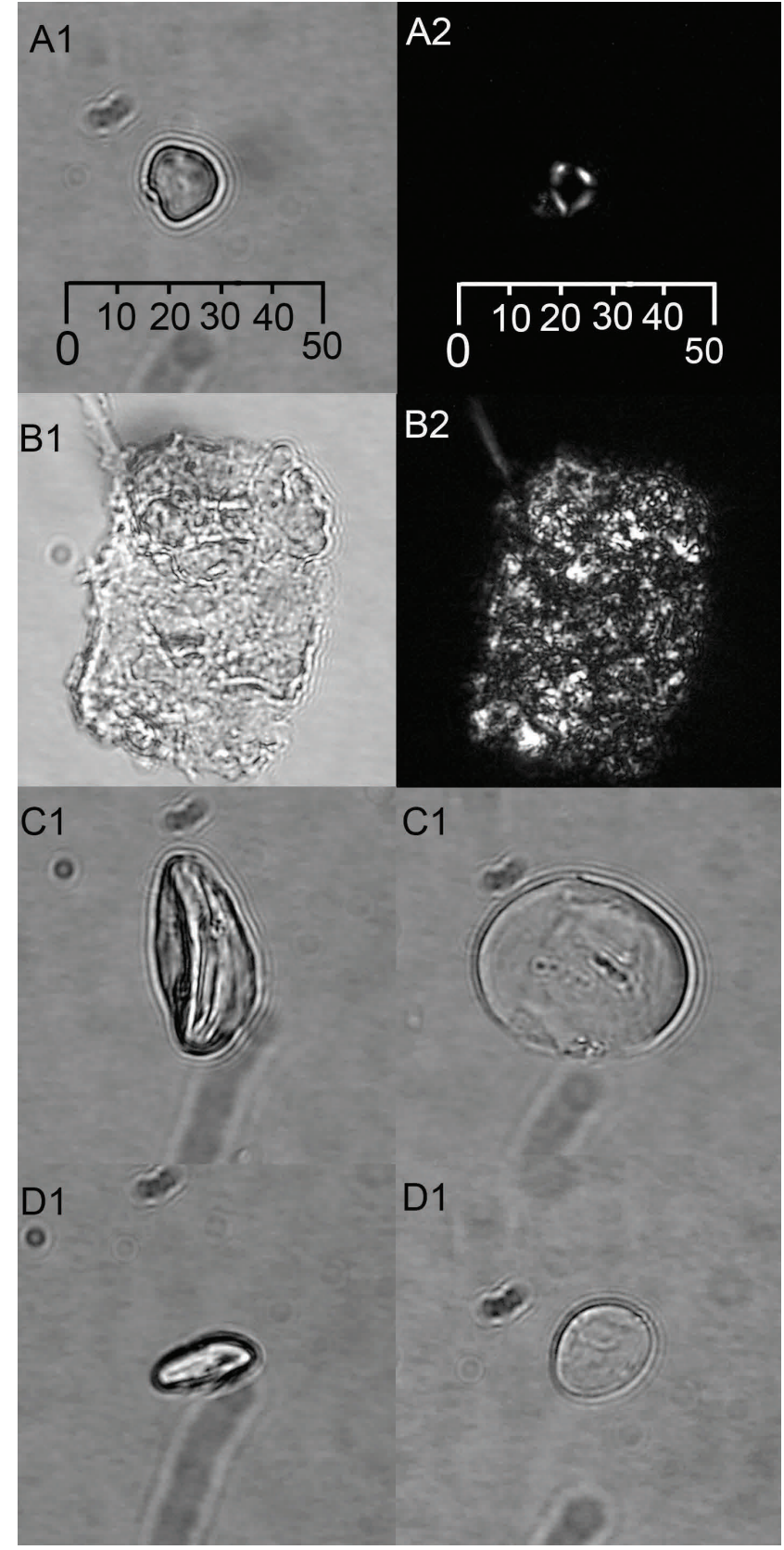

Figure 2. Cyperus esculentus L. cf. starch grain found on quartzite hoe (A1, A2). Transitory starch grains embedded in leaf tissues recovered from the large laminar debris (B1, B2). Two similar, unidentified storage starch grains recovered from the small laminar debris $(C 1, D 1)$ Transmitted light photographs are designated with a " 1 " and polarized light photographs are designated with a " 2 ". Scale bar is 50 microns.

residues (Chandler-Ezell and Pearsall 2003; Pearsall et al. 2004). The phytoliths were set aside for analysis at a later date while the starch grains were analyzed for 
Table 2. Starch grains recovered from sediment 3 samples from artifacts.

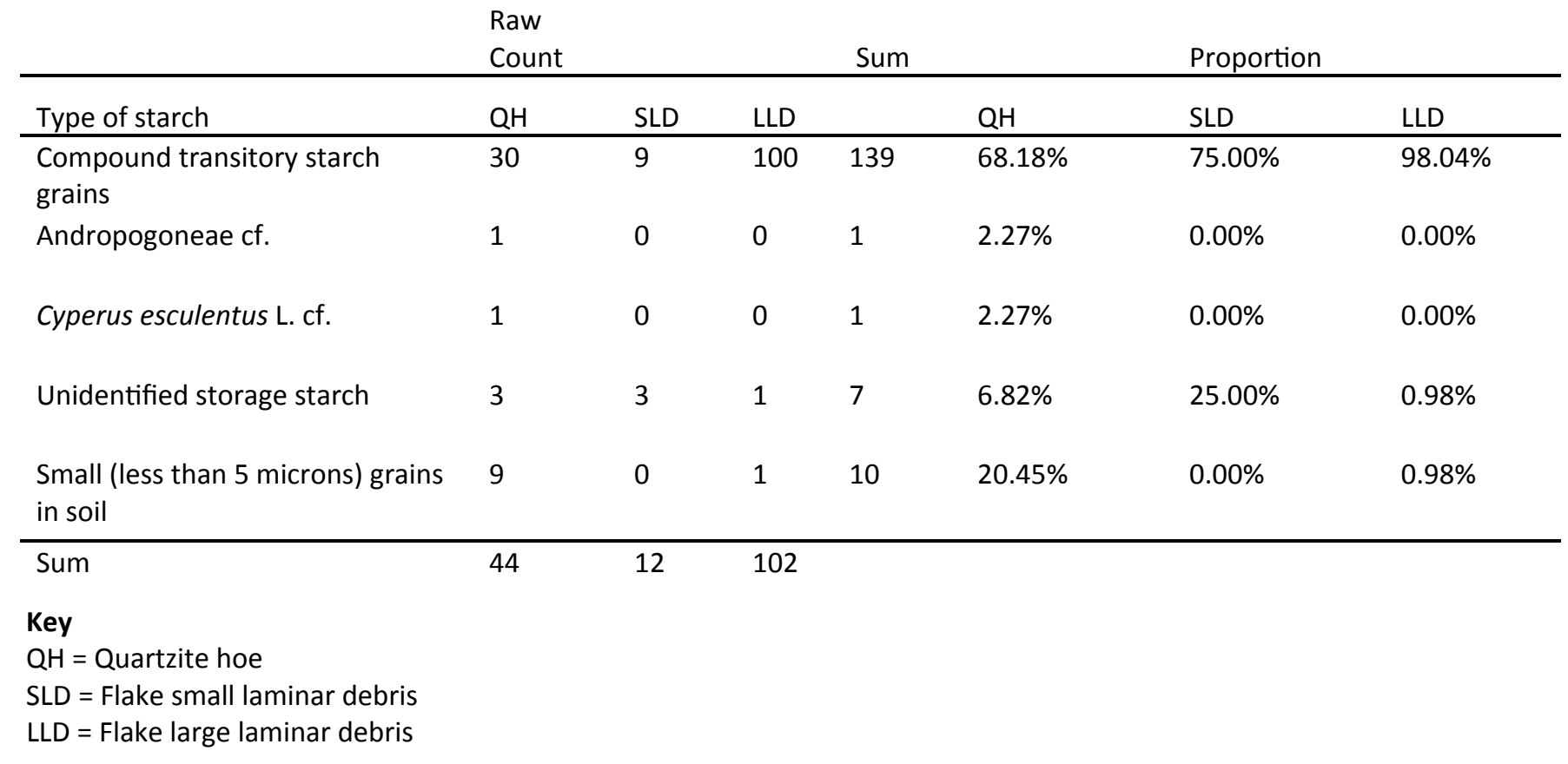

this project.

Archaeological starch grains were mounted on microscope slides using immersion oil and cover slips sealed with finger nail polish, and examined using an Olympus BX60 microscope. All starches were counted, measured, and photographed, including those that were smaller than five microns. Each slide was scanned in its entirety at 200x magnification at "dusk" with the polarizer turned halfway on thereby allowing us to see starch grain features in transmitted light and extinction crosses in polarized light at the same time. When small starch grains (those smaller than 5 microns in size) formed aggregates, they were counted as a single unit. Each individual starch grain was examined at 500x magnification in both full transmitted and polarized light and photographed using an Olympus DP10 camera. Starch grains were identified based on the starch grain comparative collection housed at the MPMRC as well as published comparative types established for the northeast United States (Messner 2011). The MPMRC comparative collection contained species represented in the macrobotanical assemblage at Sandy Hill as well as a few additional plants that may have been present at the time of occupation (McWeeney 1999). The research for this project was conducted prior to the establishment of naming protocol by the Internation- al Code for Starch Nomenclature (Perry, 2011); therefore, starch grains were described and named according to protocol established by Torrence and Barton (2006). Sediments 1, 2, and 3 were examined with sediments 1 and 2 being discarded due to potential contamination.

\section{Results and Discussion}

Both transitory and storage starch grains (Figure 2) were found on all three artifacts studied. Five types of starch grains were found on the artifacts: compound transitory starch grains, small starch grains (less than 5 $\mu \mathrm{m}$ in diameter) embedded in soil, unidentified storage starch, Andropogoneae and C. esculentus cf. starch grains. Transitory starch grains were rarely found individually but were frequently observed in compound forms, most often as aggregates preserved in vegetative tissues. A total of one-hundred and thirty-nine transitory starch grains, 2 identified storage starch grains, 7 unidentified storage starch grains, and 10 starch grains in a soil matrix were found (Table 2).

The quartzite hoe yielded thirty compound transitory starch grains, 9 small starch grains embedded in the soil, 3 unidentified storage starch, 1 Andropogoneae and 1 C. esculentus cf. starch grain. Compound transitory starch grains comprised the bulk of the material recovered from the artifact (68.18\%; Table 2). Both the Andropogoneae and $C$. 
esculentus L. cf. starch grains were identified based on the comparative criteria and dichotomous key outlined in the work pioneered by Messner (Messner 2008). The Andropogoneae starch grain is a simple twelve by twelve $\mu \mathrm{m}$ starch grain with an indistinct extinction cross, dimpled surface, rounded shape, and rounded pressure facets. The C. esculentus cf. is a simple fourteen by fourteen $\mu \mathrm{m}$ starch grain with a thick, straight, distorted extinction cross at a $90^{\circ}$ angle, smooth surface texture, and angled pressure facets (Figure 2). The unidentified storage starch grains are different from each other morphologically and ranged in size from fourteen by twenty $\mu \mathrm{m}$ to twenty four by twenty four $\mu \mathrm{m}$.

Remains recovered from the large laminar debris contained one hundred compound transitory starch grains representing $98.04 \%$ of the material (Figure 2), a single unidentified storage grain, and one small starch grain found in the soil (Table 2). The unidentified storage starch grain was a compound grain that measured fourteen by sixteen $\mu \mathrm{m}$ with a granular surface, polyhedral shape, and angled edge pressure facets. This starch grain is distinguished from compound transitory starch grains by a double wall with multiple amyloplast centers of formation associated with storage starch formation as opposed to the smaller, single-walled transitory tissues with chloroplast centers.

The small laminar debris contained only nine compound transitory starch grains and three unidentified storage grains (Table 2) or $75 \%$ and $25 \%$ of the assemblage respectively. One unidentified storage starch grain measured 14 by $16 \mu \mathrm{m}$ in size, with a smooth surface, and a thin, straight extinction cross at a $90^{\circ}$ angle. This grain could not be rolled under the microscope slide so its three-dimensional shape was impossible to determine. The two remaining storage grains were a large and small version of the same type. These grains were 22 by $24 \mu \mathrm{m}$ and 42 by $36 \mu \mathrm{m}$ respectively; had an open, centric hilum with a smooth surface and a lenticular shape. Of particular interest was the uncommon and highly diagnostic delicate, regular fissure that appeared when the starch grain was rotated into side view.

The results of this study indicate that ancient starch grains can be recovered from museum curated artifacts, and that sampling artifacts from sites like Sandy Hill can potentially offer insights into tool use and subsistence practices during New England's early Archaic period. Preliminary stone tools residue analysis, an abundance of wetland plants in the macrobotanical record, and both large and small mammal faunal data tentatively support the hypothesis that GMAT technologies are associated with an adaptation to wetland environmental exploitation. Preliminary analysis of starch grains recovered from the large and small laminar debris suggests they functioned as (or as elements of) plant-processing tools. Jones (2006) has suggested that Sandy Hill's laminar "debris" served specifically as grater-board teeth designed for shredding wetland rhizomes and tubers, seeing a possible ethnographic parallel in the stone-studded manioc shredders of South America. However, almost all of the starch grains found on the large laminar debris were transitory starch grains enmeshed in plant tissues, suggesting that this specimen was used to process leaves or stems rather than starchy tubers. Additionally, cattail and bullrush (Scirpus sp. Linnaeus Poales: Cyperaceae.) stem fragments in Sandy Hill's macrobotanical record may be unrelated to food consumption, having served as construction material for bedding, matting, rope, etc. (Perry 1999; Torrence and Barton 2006). According to the current results, we cannot presume a correlation between quartz flake production and foodprocessing. Future phytolith analysis of residues from these artifacts may be particularly useful because many wetland plants, such as those from the Cyperaceae family, produce diagnostic phytoliths in their leaves and stems (Piperno 2006).

The presence of both transitory starch grains and storage starch grains with diverse morphologies suggests that the quartzite hoe was a digging tool that was, at some point, used to harvest edible plant foods. The presence of Andropogoneae and yellow nutsedge starch grains suggests that this tool may have been used to harvest plants away from the settlement because of the widespread nature of wild grasses and yellow nutsedge in disturbed, open field environments (Lapham and Drennan 1990). Because Sandy Hill was located at the water's edge of the Great Cedar swamp, its inhabitants would have had to travel away from the swamp to find open field environments. The recovery of yellow nutsedge in the charred macrobotanical assemblage also supports the hypothesis of offsite resource use.

The unidentified storage starch grains recovered from the artifacts did not match any in the MPMRC's comparative collection or those described by Messner (2008), and may reflect the exploitation of resources 
in nearby, though ecologically distinct, environmental regimes. For example, the Long Island Sound basin, located approximately 10 kilometers south of Sandy Hill, hosted a relatively stable and potentially rich estuarine body during the $9^{\text {th }}$ millennium B.P. (Lewis 1995; McMaster and Garrison 1967). Though sea level rise has deeply submerged this ancient environment, future starch grain analysis at Sandy Hill may help confirm its exploitation. Botanical analysis at the Monte Verde II site in Chile points to the potential value of such an approach, establishing that site inhabitants gathered plant food from far afield, such as seaweed from the Pacific coast and wild potatoes from inland forests (Dillehay et al. 2008).

It is difficult to assess the use of animal resources at Sandy Hill because the excessively drained character of its glacio-deltaic sands is not conducive to bone preservation (Jones and Forrest 2003:81). Over 23,000 bone specimens have been recovered, consisting mostly of small, calcined fragments that are poorly suited for species identification or minimum number of individuals quantifications. Analysis attributes $36 \%$ of these bone specimens to mammals, and of those, $79 \%$ appear to be derived from medium and large mammals. Though a few bone specimens recovered from pit house floor strata have been confidently attributed to white tailed deer (Odocoileus virginianus Zimmermann Artiodactyla: Cervidae), the importance of hunting to Sandy Hill's Early Archaic occupants remains largely unknown.

\section{Conclusions}

This project was originally designed as a pilot study to determine whether starch grain residues preserved on excavated and subsequently curated stone tools from the early Archaic site of Sandy Hill. The results of this study do not allow us to substantially refine our view of Early Archaic subsistence practices at the site on the basis of its small sample size. However, preliminary analyses indicate that both transitory and storage starch grains survived in the pores and cracks of 8,000-year-old artifacts that were handled, washed, and curated. An abundance of transitory starch grains preserved on one of the GMAT microliths suggests that at least one of the small stone tools was used to process leaf/stem tissues. The presence of Andropogonae and yellow nutsedge starch grains on the quartzite hoe corroborates the macrobotanical record for offsite resource exploitation. The presence of reserve starch grains on all of the artifacts and the high concentrations of transitory starch grains on the large laminar debris demonstrates the potential for using starch grains to gain a better understanding of ancient plant use practices during the early Archaic period of southern New England.

There are many avenues of potential research at Sandy Hill that will expand our understanding of subsistence practices during the early Archaic and add to the growing body of knowledge related to the role that wetlands and surrounding ecosystems have played throughout human history (For other examples see Fuller et al. 2009; Neff et al. 2006; Nicholas 1998; Roberts and Rosen 2009). The first step would be to expand the existing starch grain comparative collection at the MPMRC and create a phytolith comparative collection for southern New England. Future projects should incorporate phytolith analysis and a larger number of artifacts and artifact types such as mortar and pestles. Finally, a new series of excavations would help shed light on this topic since approximately only $25 \%$ of the site has been excavated to date.

\section{Acknowledgements}

There are a great number of people and organizations whose help made this research possible. Thank you first and foremost to the Mashantucket Pequot Tribal Nation for their funding, continued support, and for allowing us to study their collections. Thank you to the Mashantucket Pequot Museum and Research Center for coordinating access to the collections and for allowing us to use their equipment. We remain indebted to Dr. Kevin McBride, Doug Currie, Roberta Charpentier, Sarah Holmes, Dr. Jason Mancini, Kathleen Boushee and the rest of the staff at the Mashantucket Pequot Museum and Research Center for their support and guidance. Doug was kind enough to permit the use of his microscope and camera. The collection, processing and scanning of comparative plant remains would not have been possible without the help of Dr. Sarah Sportman, Dr. Robert Capers, Dr. Heather Trigg, Eric Hefter, and Ashley Oakley. This collection is housed at the Mashantucket Pequot Museum and Research Center. Thank you to Dr. Timothy Messner for the advice regarding starch and ancient plant remains and to Dr. Brian Jones and Daniel Forrest for the help regarding the excavations at Sandy Hill and the Gulf of Maine Archaic. Thank you to Dr. Deborah Pearsall and Dr. 
Neil Duncan who not only processed the residues for starch grains, but also patiently answered any number of questions regarding starch grain methodology. Finally, thank you to Dr. Alexia Smith, Dr. Natalie Munro, Gabe Hrynich, and the anonymous reviewer for the helpful comments on the manuscript.

\section{Declarations}

Permissions: None declared.

Sources of funding: None declared.

Conflicts of interest. None declared.

\section{References Cited}

Barton, H. 2007. Starch residues on museum artefacts: implications for determining tool use. Journal of Archaeological Science 34:11-11.

Chandler-Ezell, K.C., Pearsall, D.M. 2003. Piggyback microfossil processing: Joint starch and phytolith sampling from stone tools. Phytolitharien 15:2-8.

Dillehay, T.D., Ramirez, C., Pino, M., Collins, M.B., Rossen, J., Pino-Navarro, J.D., 2008. Monte Verde: Seaweed, Food, Medicine, and the Peopling of South America. Science 320:784-786.

Forrest, D.T. 1999. Beyond Presence and Absence: Establishing Diversity in Connecticut's Early Holocene Archaeological Record. Bulletin of the Archaeological Society of Connecticut 62:79-99.

Fuller, D.Q., Qin, L., Zheng, Y., Zhao, Z., Chen, X., Hosoya, L.A., Sun, G.-P. 2009. The domestication process and domestication rate in rice: spikelet bases from the Lower Yangtze. Science 323:16071610.

Hart, T.C. 2011. Evaluating the usefulness of phytoliths and starch grains found on survey artifacts. Journal of Archaeological Science 38:32443253.

Haslam, M. 2004. The decomposition of starch grains in soils: implications for archaeological residue analyses. Journal of Archaeological Science 31:17151734.

Jones, B.D. 2006. A 3-Culture System Model for Early Holocene New England. Paper presented at the $46^{\text {th }}$ annual meeting of the Northeastern Antbropological Association, Albany, NY (http:// www.neaa.org/index.html).

Jones, B.D., Forrest, D.T. 2003. Life in a Postglacial Landscape: Settlement-Subsistence Change During the Pleistocene-Holocene Transition in Southern New England. In Geoarchaeology of Landscapes in the Glaciated Northeast, edited by D.L. Cremeens, and J.P. Hart, pp. 75-89. University of the State of New York, Albany, NY.

Lapham, J., Drennan, D.S.H., 1990. The Fate of Yellow Nutsedge (Cyperus esculentus) Seed and Seedlings in Soil. Weed Science 38:125-128.

Lewis, R. 1995. Geologic History of Long Island Sound. In Ecology, History, and Recreation. edited by Glenn D. Dryer and William A. Niering. pp.12-16. Connecticut College Arboretum, Bulletin No.34, New London, CT.

McMaster, R. L., and L. E. Garrison. 1967. A submerged Holocene Shoreline Near Block Island. Journal of Geography 75:335-340.

McWeeney, L. 1994. Environmental reconstruction using plant macrofossil analysis: The Mashantucket Pequot's Cedar Swamp, Report on File, Mashantucket Pequot Museum and Research Center, Mashantucket, CT.

McWeeney, L. 1999. A Review of Late Pleistocene and Holocene Climate Changes in Southern New England. Bulletin of the Archaeological Society of Connecticut 62:3-18.

Messner, T.C. 2008. Woodland Period Period People and Plant Interactions: New Insights from Starch Grain Analysis. Unpublished Doctoral Dissertation, Department of Anthropology, Temple University, Philadelphia, PA.

Messner, T.C. 2011. Acorns and Bitter Roots: Starch Grain Research in the Prehistoric Eastern Woodlands. University of Alabama Press, Tuscaloosa, AL.

Neff, H., Pearsall, D.M., Jones, J.G., Arroyo, B., Collins, S.K., Freidel, D.E. 2006. Early Maya Adaptive Patterns: Mid-Late Holocene Paleoenvironmental Evidence from Pacific Guatemala. Latin American Antiquity 17: 287-315.

Nicholas, G.P. 1998. Wetlands and Hunter-Gatherers: A Global Perspective. Current Anthropology 39: 720 731.

Pearsall, D.M. 2000. Paleoethnobotany : a handbook of procedures, Academic Press, San Diego, CA.

Pearsall, D.M. Chandler-Ezell, K.C., Zeidler, J.A. 2004. Maize in ancient Ecuador: results of residue analysis of stone tools from the Real Alto site. 
Journal of Archaeological Science 31:423-442.

Perry, D., 1998. Interim report on the analysis of vegetative plant remains from sites 72-97, 72-91, and 72-66. Report on File, Mashantucket Pequot Museum and Research Center, Mashantucket, CT.

Perry, D., 1999. Charred Vegetative Plant Tissues from Site 72-97: Preliminary Results. Report on File, Mashantucket Pequot Museum and Research Center, Mashantucket, CT.

Perry, D. 2000. Vegetative plant remains from site 72163. Report on File, Mashantucket Pequot Museum and Research Center, Mashantucket, CT..

Perry, L.L. 2011. The International Code for Starch Nomenclature. Foundation for Archaeobotanical Research in Microfossils. Available at: http:/ / fossilfarm.org/ICSN/Code.html. Accessed on February 19, 2013.

Piperno, D.R. 2006. Phytoliths : a comprehensive guide for archaeologists and paleoecologists. AltaMira Press, Lanham, MD.

Piperno, D.R., Weiss, E., Holst, I., Nadel, D. 2004. Processing of wild cereal grains in the Upper Palaeolithic revealed by starch grain analysis. Nature 430:670-673.

Reichert, E.T. 1913. The Differentiation and Specificity of
Starches in Relation to Genera, Species, Etc., Stereochemistry Applied to Protoplasmic Processes and Products and as a Strictly Scientific Basis for the Classification of Plants and Animals. The Carnegie Institute of Washington, Washington D. C.

Roberts, N., Rosen, A.M. 2009. Diversity and Complexity in Early Farming Communities of Southwest Asia: New Insights into the Economic and Environmental Basis of Neolithic Çatalhöyük. Current Anthropology 50:393-402.

Robinson, B.S., Peterson, J.B. 1993. Perceptions of marginality: the case of the early Holocene in northern New England. Northeast Anthropology 46:61 -75 .

Thorson, R.M., Webb, R.S. 1991. Postglacial history of a cedar swamp in southeastern Connecticut. Journal of Paleolimnology 6:17-35.

Torrence, R., Barton, H., eds. 2006. Ancient Starch Research. Left Coast Press, Walnut Creek, CA.

\section{Biosketch}

Thomas C. Hart is pursuing his PhD in Anthropology at the University of Connecticut. His research focuses on subsistence and social complexity in Mesopotamia.

Timothy H. Ives is Timothy $\mathrm{H}$. Ives is the Principal Archaeologist at the Rhode Island Historical Preservation and Heritage Commission. 